\title{
Nursing diagnoses and outcomes for children with nutritional anomalies: a descriptive study
}

\author{
Diagnósticos e resultados de enfermagem à criança com alteração nutricional: estudo descritivo
}

Los diagnósticos y resultados de enfermería sobre niños con alteración nutricional: un estudio descriptivo

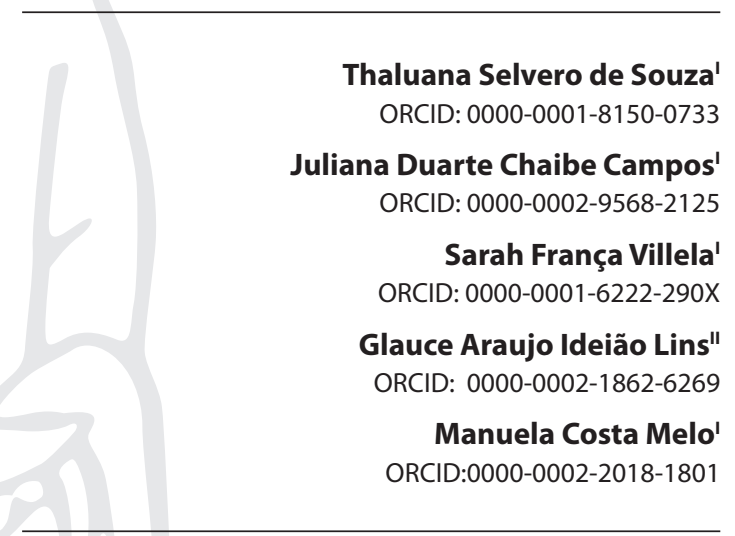

'Escola Superior em Ciências da Saúde. Brasília, Distrito Federal, Brazil.

"Secretaria de Saúde do Distrito Federal. Brasília, Distrito Federal, Brazil.

How to cite this article:

Souza TS, Campos JDC, Villela SF, Lins GAI, Melo MC. Nursing diagnoses and outcomes for children with nutritional anomalies: a descriptive study. Rev Bras Enferm. 2020;73(3):e20180809. doi: http://dx.doi.org/10.1590/0034-7167-2018-0809

\section{Corresponding author:}

Manuela Costa Melo

E-mail:melomanuela91@gmail.com

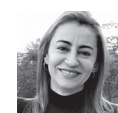

EDITOR IN CHIEF: Dulce Aparecida Barbosa ASSOCIATE EDITOR: Marcos Brandão

Submission: 10-16-2018

Approval: 04-30-2019

\begin{abstract}
Objectives: to develop nursing diagnoses and outcomes for children with nutritional anomalies based on terms found in a children's clinical protocol and on the 2017 International Classification for Nursing Practice. Methods: exploratory-descriptive study, conducted with the validation of diagnoses/outcomes by six nurses of the children's clinic of the Federal District's teaching hospital. It was based on the cross-mapping between the terms of International Classification for Nursing Practice 2017 and the terms of a children's health care protocol. The list of nursing diagnosis/outcomes was developed, then submitted to the validation process using a Likert-type scale and considering statements with content validity index $>0.79$ to be validated. Results: a total of 51 diagnoses/outcomes were generated, and of those, 11 were contained in International Classification for Nursing Practice. Those that were not in it were evaluated for similarity and comprehensiveness in relation to International Classification for Nursing Practice. Thirty nursing diagnoses/outcomes were validated with $\mathrm{CVI}>0.79$ among the nurses in the validation process. Conclusions: this study will allow the formation of a terminological International Classification for Nursing Practice subset aimed at children's nutrition.
\end{abstract}

Keywords: Standardized Nursing; Terminology Child Health; Child Health; Integrality in Health; Pediatric Nursing.

\section{RESUMO}

Objetivos: elaborar enunciados diagnósticos e resultados de enfermagem à criança com alteracão nutricional a partir de termos encontrados em protocolo clínico pediátrico e a Classificação Internacional para a Prática de Enfermagem 2017. Métodos: estudo exploratóriodescritivo, realizado com validação de diagnósticos/resultados por seis enfermeiras da clínica pediátrica do hospital-escola do Distrito Federal. Realizou-se mapeamento cruzado entre os termos da Classificação Internacional para a Prática de Enfermagem 2017 com termos do protocolo de atenção à saúde da criança. Foram elaborados a lista de diagnósticos/resultados de enfermagem, essa lista foi submetida ao processo de validação com utilização da escala tipo Likert por meio do índice de validade de conteúdo, que considera validado o enunciado que possuir IVC > 0,79. Resultados: gerados 51 enunciados diagnósticos/resultados, dessas, 11 constantes na Classificação Internacional para a Prática de Enfermagem. Os diagnósticos não constantes foram avaliados conforme similaridade e abrangência à Classificação Internacional para a Prática de Enfermagem. 30 enunciados diagnósticos/resultados de enfermagem foram validados, possuindo ICV > 0,79 entre os enfermeiros, no processo de validação. Conclusão: este estudo possibilitará a formação de um subconjunto terminológico Classificação Internacional para a Prática de Enfermagem voltado à nutrição da criança.

Descritores: Diagnósticos de Enfermagem; Cuidados de Enfermagem; Educação em Saúde; Análise estatística; Teoria de Enfermagem.

\section{RESUMEN}

Objetivos: elaborar enunciados diagnósticos y resultados de enfermería sobre el niño con alteración nutricional a partir de términos encontrados en el protocolo clínico pediátrico y en la Clasificación Internacional para la Práctica de Enfermería 2017. Métodos: estudio exploratoriodescriptivo, con la validación de diagnósticos/resultados realizada por seis enfermeras de una Clínica pediátrica del Hospital-Escuela del Distrito Federal (Brasil). Se realizó un mapeo cruzado entre los términos de la Clasificación Internacional para la Práctica de Enfermería 2017 y los términos del Protocolo de Atención Sanitaria del Niño. Se elaboró una lista de diagnósticos/ resultados de enfermería, a la cual se sometió al proceso de validación, que utilizó la escala tipo Likert por medio del índice de validez de contenido, que considera válido el enunciado que posee IVC > 0,79. Resultados: de los 51 enunciados diagnósticos/resultados obtenidos, 11 estaban presentes en la Clasificación Internacional para la Práctica de Enfermería. Los diagnósticos no presentes se evaluaron mediante la similitud y el alcance de la Clasificación Internacional para la Práctica de Enfermería. Treinta enunciados diagnósticos/resultados de enfermería con ICV > 0,79 fueron validados por los enfermeros en el proceso. Conclusiones: este estudio puede permitir la formación de un subconjunto terminológico Clasificación Internacional para la Práctica de Enfermería en torno a la nutrición del niño.

Descriptores: Diagnóstico de Enfermería; Atención de Enfermería; Educación en Salud; Análisis Estadístico; Teoría de Enfermería. 


\section{INTRODUCTION}

The nursing process (NP) is a methodological instrument that has the purpose of identifying, describing, understanding, and explaining how customers respond to problems related to the health-disease process, defining the moment when there is need for professional intervention and for the conducts to be adopted $^{(1-2)}$. This instrument facilitates the reasoning, care and proper documentation of the nursing practice. It is a sequential, cyclical instrument, the phases of which can be incorporated and reworked if necessary, thus resulting in the complete, coherent and individualized care of patients.

Every NP needs the support of the nursing theory that most fits the type of care being offered. Nursing theories are the scientific basis of nursing practices and of the NP(2-4). Wanda Aguiar Horta's Theory of Basic Human Needs (TNHB) ${ }^{(5)}$, based on Abraham Maslow's Theory of Human Motivation ${ }^{(6)}$, is a theory that is widely used in various clinics, which seeks to identify the human needs of patients and, from them, draw individualized actions plans.

Childhood is a period characterized by known vulnerability, both in relation to care and physiology. The process of growth and development requires a series of interventions and stimuli, the inadequate consumption of nutrients, excesses or deficiencies ${ }^{(7-8)}$, being determinant in this process. Anomalies of this need can generate serious consequences for the child, from diarrhea, respiratory diseases, infections ${ }^{(8)}$ and delays in development to death, these conditions being the main causes for hospitalization in this age range.

In hospital services, in the case of this study, in the children's clinic, nurses may have difficulties in the deployment of the Systematization of Nursing Care (SAE), due to the numerous demands they need to meet, showing difficulties also in the NP's application ${ }^{(9)}$. The development of terminological subsets of the International Classification for Nursing Practice (ICNP) can facilitate the classification's use in health services. The terms contained in ICNP's Seven-Axis model ${ }^{(10)}$, when combined, produce nursing diagnoses in accordance with norm ISO 18.104 for development of nursing terminologies, published in 2003 and updated in 2014(1,11).

Considering the complexity of the clients admitted to the children's unit of a teaching hospital in Brasília, the vulnerability of childhood, the importance of nutritional aspects, the difficulties shown by the team in SAE's implementation, and the need for strengthening the standardized language, the following question is made: how to develop a list of nursing diagnoses/outcomes related to nutritional anomalies in children?

\section{OBJECTIVES}

To develop validated nursing diagnoses/outcomes for hospitalized children with nutritional anomalies from the terms found in a children's clinical protocol and ICNP 2017.

\section{METHODS}

\section{Ethical aspects}

This study received the approval of the Research Ethics Committee of Fundação de Ensino e Pesquisa em Ciências da Saúde do Distrito Federal, and its development met the national and international ethical standards for research involving human beings.

\section{Study design, location and period}

This is an exploratory-descriptive study held at the children's clinic of a teaching hospital of the Brazilian Unified Health System (SUS) located in Brasília, Federal District (DF). It was conducted between November 2017 and February 2018.

\section{Study protocol}

The study was carried out in two steps. The first was documentary, based on the collection of data from primary care protocol No. 33, drafted by the Ministry of Health, for children's health care practices ${ }^{(8)}$, and from ICNP's Seven-Axis model, 2017 version. For the choice of this protocol, the following inclusion criteria were established: a) year of publication of its newest edition, b) availability in full and c) comprehensiveness of the content relating to the health of children in the growth and development process. The exclusion criteria were: a) publications with a format other than protocol, b) documents that were not written in Portuguese, because the study demanded semantic equivalence, in addition to literal translations, c) documents published before 2012; and d) themes involving anything other than children's health. This step resulted in the construction of the ICNP 2017 terminology bank, where the content was standardized in relation to the terms of ICNP 2017.

In the second step, cross-mapping between the terms of ICNP 2017 and the terms of primary care protocol No. $33^{(8)}$, adopted by the Ministry of Health for children's health, was conducted, and the terms of the protocol found to be constant in the seven axes of ICNP 2017 were highlighted, the development of the nursing diagnoses/outcomes (ND/NO) ${ }^{(1,11)}$ related to anomalies in children's nutrition having been conducted from the term-by-term evaluation of their respective definitions/concepts in scientific articles and in a dictionary of medical term $\mathrm{s}^{(12)}$. For signs and symptoms, the focus axis was adopted, and for other situations, the focus and judgment axes were adopted, following ISO 18.104.2014 (113).

The ND/NO were developed in Excel spreadsheet and put in alphabetical order, after which standardization was carried out according to ICNP. In this way, cross-mapping ${ }^{(11)}$ was conducted between the ND/NO developed in the study and ICNP's in software Access For Windows 2007, where those contained and not contained in ICNP were identified, then separated according to Leal's criteria ${ }^{(1)}$, which evaluates similarity and coverage according to comprehensiveness, restrictiveness and lack of agreement with ICNP. All ND/NO identified resulted in a list of those related to children's nutritional anomalies.

The instrument used for validation of the ND/NO developed was a Google Forms questionnaire, created by using a Likert-type scale ${ }^{(1)}$, in which the "big box" model was chosen, containing lines with the nursing diagnoses/results and columns with the scale's values, which in this study ranged from one to four, the concepts being: 1 classified as "irrelevant", 2 as "not very relevant", 3 as "relevant" and 4 as "very relevant".

The list of ND/NO developed was subjected to a validation process with professional nurses in the children's health department of a teaching hospital in Brasília. 


\section{Population and inclusion and exclusion criteria}

For the choice of the nurses, the following inclusion criteria were established: a) having a degree in Nursing; b) having professional experience of more than one year in the area of children's nursing; and the exclusion criteria were: a) professionals from other categories and nurses on leave from work in the Children's Unit for more than 6 months. The selection was carried out by convenience, six nurses with experience in the Children's Clinic having been chosen for this study. The signing of the informed consent form was carried out in loco, on a prearranged date and time, after which the validation process was conducted.

\section{Analysis of results and statistics}

The Content Validity Index (CVI) was used in the validation process to measure the percentage of agreement of the ND/NO with a particular aspect of the instrument and its items, assessing their relevance for clinical practice ${ }^{(1)}$.

The questionnaire was answered by the nurses in the Children's Unit, with a portable electronic device (tablet), in the period between January and February 2018. Each professional analyzed the items individually, in their own time - 30 to 40 minutes on average - assigning to each of the questionnaire's items the score on the Likert-type scale they deemed as most appropriate $^{(14)}$. After filling the instrument, each professional selected the option "send", ensuring that their answers would be computed with no alterations. All questionnaires filled were automatically included in the Google Forms graph by the program itself, and subsequently analyzed, with estimation of the content validity index (CVI) of each ND/NO by using the average of each item's values, all the CVI attributed to the respective item judged by each professional having been added up, according to the Likert scale, then estimated and divided by the number of answers ${ }^{(1)}$, as in the formula: (V1 + V2 + V3 + V4 + V5 + V6)/6, where "V" stands for the "value" of the Likert scale assigned by each professional to the item being evaluated, the numbers stand for the professionals involved, and the divisor, for the number of answers.

In the case of this study, as there were six judges, the items need to have an agreement index greater than or equal to 0.8 , which corresponds to those that received a mean score between three and four on the aforementioned scale, these being considered validated items. The items deemed as valid will represent the ND/NO used in the creation of a terminological ICNP subset for children with nutritional anomalies.

\section{RESULTS}

Of the terms taken from the children's health protocol - adopting the language of ICNP nursing for the protocol's terms -, of the 10,500 terms mapped, 402 were distributed as follows: focus (223); judgement (16); action (23); location (64); medium (42); client (17); time (17) (Figure 1).

The ND/NO were developed from the terms identified in the children's health protocol and ICNP's Seven Axes based on the TNHB, in relation to children's nutritional aspects, generating a list with 51 items. Of this total, 11 items were contained in ICNP
2017 in the sector of Nursing Diagnoses and Outcomes, and 40 were not contained in it.

Contained items mapped

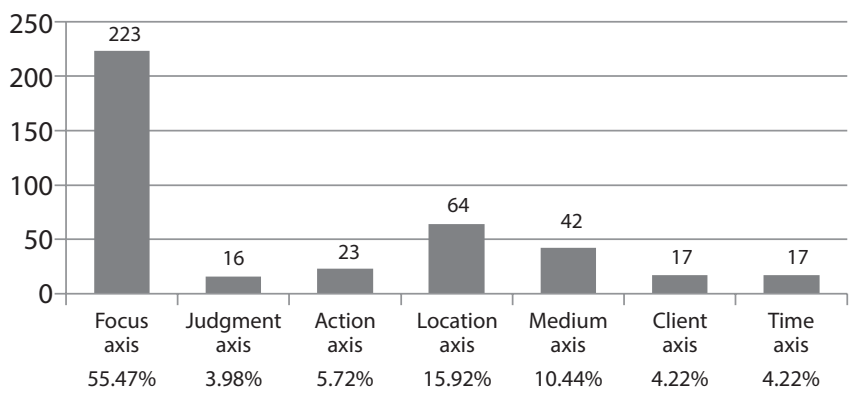

Figure 1 - Distribution of the terms mapped between the protocol and International Classification for Nursing Practice by axis

The latter were analyzed in relation to similarity and comprehensiveness, which resulted in a share of 19 similar items (47.5\%), 2 more comprehensive items (5\%), 10 more restricted items (25\%) and 9 items without agreement (22.5\%).

All items, both those contained and not contained, generated a list of ND/NO related to the nutrition of hospitalized children, which was subjected to a validation process with the nurses, using a Likert-type scale.

The analysis of the graph generated with the filling of the Google Forms questionnaire and estimation of the mean Likerttype scale scores for each ND/NO showed that of the 51 items developed, 30 (58\%) had CVI > 0.79, i.e., were validated, and 21 (42\%) had $\mathrm{CVI}<0,79$, i.e, were not validated (Table 1).

Table 1 - Relation of the nursing diagnoses/outomes with their mean Likert-type scale scores

\begin{tabular}{lc}
\hline $\begin{array}{l}\text { Nursing diagnoses/outcomes for } \\
\text { children with nutritional anomalies }\end{array}$ & $\begin{array}{c}\text { Mean Likert } \\
\text { scale score }\end{array}$ \\
\hline Normal child development & 2.1 \\
Low swallowing & 2.5 \\
Breastfeeding dependency & \\
Fainting & \\
Moderate acceptance of food & \\
Presence of bulimia & \\
Presence of food intake & \\
Low energy (fatigue) & \\
Low mastication & \\
Impaired dentition & \\
Breast engorgement & \\
Normal metabolism & \\
Presence of appetite & \\
Presence of swallowing & \\
Presence of hyperactivity & \\
Presence of laceration of maternal breast & \\
Presence of suction & \\
Risk of bulimia & \\
Low child development & \\
Delay in child development & \\
Presence of intestinal obstruction & \\
Risk of malnutrition & \\
Risk of diarrhea & \\
Risk of hypoglycemia & \\
Risk of vomiting & \\
\hline
\end{tabular}

To be continued 
Table 1 (concluded)

\begin{tabular}{lc}
\hline $\begin{array}{l}\text { Nursing diagnoses/outcomes for } \\
\text { children with nutritional anomalies }\end{array}$ & $\begin{array}{c}\text { Mean Likert } \\
\text { scale score }\end{array}$ \\
\hline Hypoglycemia & 3.1 \\
Nausea & \\
Obesity & \\
Slow bowel movements & \\
Risk of pulmonary aspiration & \\
Risk of constipation & 3.3 \\
Delay in child development & \\
Low absorption of vitamins & \\
Low adherence to hospital food & \\
Low food intake & \\
Low suction & \\
Low access to food & \\
Abdominal discomfort & \\
Diabetes & \\
Dyslipidemia & \\
Food allergy & \\
Low acceptance of food & \\
Low metabolism & \\
Constipation & \\
Dehydration & \\
Encopresis & \\
Presence of appetite & \\
Diarrhea & \\
Abdominal pain & \\
Normal food intake & \\
Malnutrition & \\
Vomiting & \\
\hline & \\
\hline
\end{tabular}

The ND/NO that received the highest scores were: malnutrition and vomiting (score 3.8); diarrhea, abdominal pain and normal food intake (score 3.6). Of the validated ND/NO, 8 were contained in ICNP and 22 were not. Those excluded in the validation, i.e., those with $\mathrm{CVI}<0.8$, represented a total of $21 \mathrm{ND} / \mathrm{NO}$ developed in this study, corresponding to $42 \%$.

The ND/NO with the highest rejection rates were: a) normal child development (score 2.1); b) low swallowing, breastfeeding dependency;c) fainting, d) moderate acceptance of food; e) presence of bulimia; and f) presence of food intake (score 2.5). Of the non-validated ND/NO, 3 were contained in ICNP and 18 were not.

\section{DISCUSSION}

The 2010 population census data of the Brazilian Institute of Geography and Statistics (IBGE) show that despite the population's aging, a large portion of it consists of children and adolescents - of the more than 190 million inhabitants of Brazil, about 29 million are children aged between 0 and 9 years old, and 35 million are children and young people aged between 10 and 19 years old, totaling about 63 million children and young people. Percentagewise, in 2010 the census concluded that $24.08 \%$ of the Brazilian population was composed of children between 0 and 14 years old $^{(15)}$. Children represent a group with great vulnerability due to rapid growth and physiological and immunological immaturity.

The Brazilian child population has been showing alarming growth rates in anthropometric indicators over the years, as well as imbalance of the individual's basic needs. The Family Budgets Survey (POF) (2008-2009) showed the evolution of the indicators of Brazilian children between 5 and 9 years old, amongst which the rate of those who are overweight increased from $10.9 \%$ in
1974-1975 to $34.8 \%$ in $2008-2009$, for boys, and from $8.6 \%$ to $32 \%$ for girls, in the same period ${ }^{(8)}$.

Nutrition directly influences physical growth, neuro-psychomotor development and the immune system, preventing infectious diseases ${ }^{(16)}$. Nutrition disorders are singled out as primary causes of morbidity and mortality and constitute one of the complicating factors that compromise the prognosis of human diseases ${ }^{(17)}$.

Given the relevance of the nutritional issue for children's health and nursing practice, its relationship with the NHB can be defined as "states of conscious or unconscious tensions resulting from the imbalance of the basic needs of the individual, family and community, demanding the resolution of the problems found from the nurse ${ }^{\prime \prime(18)}$. The NHB are divided into subcategories: a) psychobiological; b) psychosocial; and c) psycho-spiritual. Among the psychobiological needs, the children's nutrition subcategory, in the Brazilian population, highlights important pathological anomalies, being associated with dyslipidemia, obesity ${ }^{(8,19)}$, and with the growing emergence of diabetes mellitus type II $^{(19)}$. Other important anomalies are related to food deficits. Brazil has achieved its goals concerning the reduction of child malnutrition, but despite the improvement of access to health and the increase of the population's income, the indicators relating to micronutrient deficiencies remained high ${ }^{(16)}$.

The nutritional evaluation should be performed by health professionals in children with nutritional risk, which should have their weight and height data measured, evaluated according to the growth and development curves and sorted according to the weight/height, height/age, body mass index/age and weight/ age rates ${ }^{(20)}$. This practice is part of the everyday life of nursing in children's health care, in all levels of care.

In nursing practice, notes provide subsidies to the nurse in the establishment of the care plan and support the reflective analysis of the care delivered. Nursing records are essential for the development of SAE, according to Cofen Resolution No. $358 / 2009$, because they are a source of necessary information to ensure the continuity of care ${ }^{(21)}$, for being performed by a specific professional who assumes a series of dynamic, interrelated actions, which make it possible to individualize care, transform the nursing practice, and serve as a basis for developing the ND/NO.

In this study, 30 of the developed ND/NO, representing 58\% of the total, had CVI > 0.79, having been thus validated. Other studies using a similar method also resulted in approval of the nursing diagnoses/outcomes $>50 \%{ }^{(22)}$.

The ND/NO with the highest validation rates in this study were: a) malnutrition and vomiting (score 3.8 ), which relate to the signs and symptoms with significant prevalence in cases of nutritional deficits, along with item b) diarrhea (score 3.6), as described in some studies focused on the subject. Both items are frequent situations in the children's clinic, along with abdominal pain (score 3.6) and dehydration (score 3.5), which are relevant $\mathrm{ND} / \mathrm{NO}$ in cases of gastroenteritis and diarrhea.

The ND/NO food allergy (score 3.5) is shown to be a current public health problem, with increasing prevalence over the decades, being defined as a pathology related to abnormal immune response that occurs after ingestion/contact with a certain food, and which may be an immune reaction or not. In childhood, the foods that are most often related to food allergies are cow's milk, egg, wheat and soy, which are widely used foods(23-24). 
The items: low acceptance of food, low metabolism, constipation and encopresis (3.5) are associated with the current nutritional transition, arising from changes in the dietary structure, related to socioeconomic, demographic changes and to the accelerated industrialization process affecting food culture ${ }^{(7.19)}$. Normal food intake (score 3.6) and presence of appetite (score 3.5) were the only positive ND/NO.

The validated diagnoses still need to be subjected to clinical validation, and with their use in practice, can be adapted to the reality of health care services ${ }^{(2)}$. The non-validation of the 21 developed items, which correspond to $42 \%$ of the total, may be related to specific characteristics of the environment, to working conditions ${ }^{(25)}$, and to the professionals' excessive demands in their clinical practice. During the filling of the questionnaires, demands with distinct complexities appeared before the nurses.

Considering the hospital environment, some items may have been judged as non-priority, which may also have influenced the non-validation of some of this study's nursing diagnoses/outcomes ${ }^{(26)}$, given the complexity of children's health. We also observed that several nursing diagnoses/results received $\mathrm{CVI}<0.80$ due to the nurses' prioritizing of nutritional deficiencies and caloric excesses.

Studies reinforce that the nutrition of Brazilian children features high inadequacy of the consumption of micronutrients and also caloric excesses ${ }^{(25-26)}$. The low rate of exclusive breastfeeding until the child is 6 months old should be taken into consideration, as well as the food available to children in school canteens ${ }^{(26)}$, which adds greater vulnerability to their nutritional imbalance.

Considering the different regions of the country, there is prevalence of either nutritional deficiency or excesses ${ }^{(27)}$. Considering the public seen in this study's unit, it can be inferred that some items may not have been validated according to the reality of this population.

The relevance of this study should be emphasized, seeing as the nutrition of Brazilian children is recognized as a public health problem ${ }^{(28-30)}$, the offer of systematic care to children with nutritional anomalies being thus important to promote a high quality, coherent, cyclical and individualized care, in accordance with the nursing process $\mathrm{p}^{(4,9,22)}$.

\section{Study limitations}

Limitations were found in this study, namely: the difficulty to find similar studies; studies that described Wanda Horta's subcategories in detail; and the adherence of the research participants for validation of the ND/NO. Despite these limitations, the study reached its goal, as it presented the nursing diagnoses and outcomes developed for children's nutritional anomalies.

\section{Contributions to the field of nursing, health or public policy}

This study will aid the implementation of the systematization of care in the children's clinic, facilitating the nurses' clinical reasoning and decision-making in relation to children's nutritional anomalies. The validated diagnoses/outcomes can be used in practice and will strengthen the use of ICNP 2017. The use of the nursing process suggests diagnoses and outcomes that are not listed in ICNP. The study will allow the construction of a terminological ICNP subset related to children's nutritional anomalies, containing the NR/NO and their respective interventions and, later, the construction of a terminological ICNP subset for the health of hospitalized children.

\section{CONCLUSIONS}

The use of special nursing languages has great importance to ensure clear communication and the systematization of an accurate, organized and individualized nursing care.

The ND/NO malnutrition, vomiting, diarrhea, abdominal pain, normal food intake, food allergies, low acceptance of food, low metabolism, constipation, dehydration, encopresis, presence of appetite, delay in child growth, low absorption of vitamins, low adherence to hospital food, low food intake, low suction, low access to food, abdominal discomfort, diabetes, dyslipidemia, hypoglycemia, nausea, obesity, slow bowel movements, risk of pulmonary aspiration, risk of constipation, risk of malnutrition, risk of diarrhea, risk of hypoglycemia and risk of vomiting, which have been validated in this study, may be used by professionals working in the field of children's health after being subjected to clinical validation.

The development of the nursing diagnoses/results for children with nutritional anomalies covers only one of the various aspects of children's health. It is believed that this study may inspire scholars to construct terminological ICNP subsets in different hospital units.

The follow-up of this study is necessary for the structuring of nursing interventions related to each of the nursing diagnoses/outcomes, to be used in the construction of a terminological ICNP subset for hospitalized children with nutritional anomalies. The use of ICNP subsets in clinical practice strengthens the standardized nursing language, the systematization of care and the use of ICNP as a unifying language, thus promoting nursing practice, education and research.

\section{REFERENCES}

1. Cubas MR, Nóbrega MML. Atenção primária em saúde: diagnósticos, resultados e intervenções de enfermagem. Rio de Janeiro: Elsevier; 2015 .

2. Trindade LR, Ferreira AM, Silveira A, Rocha EN. Processo de enfermagem: desafios e estratégias para sua implementação sob a ótica de enfermeiros. Saúde (Santa Maria) [Internet]. 2016[cited 2018 Apr 12];42(1):75-82. Available from: http://dx.doi.org/10.5902/2236583419805

3. Silveira RCP, Robazzi MLCC. Nursing assessment of adults and older adults and the basic human needs theory: a reflection. Rev Enferm UFPE. 2014;8(10):3525-32. doi: 10.5205/reuol.6039-55477-1-ed.0810201432

4. Pereira PJS, Souza NFH, Almeida RJ, Menezes DC, Bom GC, Trettene AS. Nursing diagnoses and interventions in children submitted to cochlear implantation. Rev Esc Enferm USP [Internet]. 2017 [cited 2018 Jan 14];51:e03238. Available from: http://dx.doi.org/10.1590/ S1980-220X2016045203238 
5. Pinheiro AM, Tannure MC. SAE: Sistematização da Assistência de Enfermagem: guia prático. 2a ed. Rio de Janeiro: Guanabara Koogan; 2010.

6. Castro LS, Castro GS. A motivação em foco: uma revisão de literatura acerca das teorias motivacionais de Maslow e Herzberg, suas semelhanças, diferenças e contribuições para o administrador moderno. Rev Diál Ciênc[Internet]. 2016[cited 2017 Apr 20];1(36):1-26. Available from: periodicos.ftc.br/index.php/dialogos/article/view/54

7. Carvalho CA, Fonsêca PCA, Priore SE, Franceschini SCC, Novaes JF. Food consumption and nutritional adequacy in Brazilian children: a systematic review. Rev Paul Pediatr [Internet]. 2015[cited 2018 Jan 30];33(2):211-21. Available from: http://dx.doi.org/10.1016/j.rpped.2015.03.002

8. Ministério da Saúde (BR). Saúde da criança: crescimento e desenvolvimento [Internet]. Cadernos de Atenção Básica, n 33.2012 [cited 2017 Dec 24]. Available from: http://bvsms.saude.gov.br/bvs/publicacoes/saude_crianca_crescimento_desenvolvimento.pdf

9. Silva FR, Prado PF, Carneiro JA, Costa FM. Implementação da sistematização da assistência de enfemagem: dificuldades e potencialidades. Revista da Universidade Vale do Rio Verde [Internet]. 2014[cited 2018 Jan 30];12(2):580-90. Available from: http://periodicos.unincor.br/ index.php/revistaunincor/article/view/1609

10. Garcia TR. Classificação Internacional para a Prática de Enfermagem. 2nd ed. Porto Alegre: Artmed; 2017.

11. Albuquerque LM. Construção de subconjunto terminológico CIPE para crianças e adolescentes vulneráveis à violência doméstica[Dissertação]. São Paulo (SP): Universidade São Paulo; 2014. Available from: http://www.teses.usp.br/teses/disponiveis/83/83131/tde-09012015-155552/es.php

12. Rey L. Dicionário de termos técnicos de medicina e saúde. 2nd ed. Rio de Janeiro: Guanabara Koogan; 2003.

13. Marin HF, Peres HHC, Sasso GTMD. Análise da estrutura categorial da Norma ISSO 18104 na documentação em Enfermagem. Acta Paul Enferm [Internet]. 2013 [cited 2018 Jan 20];26(3):299-306. Available from: http://dx.doi.org/10.1590/S0103-21002013000300016.

14. Silva Jr SD, Costa FJ. Measurement and verification scales: a comparative analysis between the Likert and phrase completion scales. PMKT [Internet]. 2014 Oct [cited 2019 Mar 13]; 15(1)1-16. Available from: https://pt.scribd.com/ document/299659824/1-Mensuracao-e-Escalas-de-Verificacao-Uma-Analise-Comparativa-Das-Escalas-de-Likert-e-Phrase-Completion

15. Instituto Brasileiro de Geografia e Estatística (BR). Censo Demográfico 2010 [Internet]. 2010 [cited 2017 Apr 24]. Available from: http://www. ibge.gov.br/home/estatistica/populacao/censo2010/default.shtm

16. Vaz MA, Oliveira GG, Pinheiro MS, Medeiros EFF. Suplementação na infância e a prevenção da carência de micronutrientes. Rev Med Saúde [Internet]. 2017 [cited 2017 Apr 29];6(1):116-131. Available from: https://portalrevistas.ucb.br/index.php/rmsbr/article/view/7684/5108

17. Lopez FA, Campos Júnior D, organizers. Tratado de pediatria: Sociedade Brasileira de Pediatria. 2nd ed. Barueri: Manole; 2010.

18. Horta WA. Processo de enfermagem. Rio de Janeiro: Guanabara Koogan; 2011.

19. Zeitler P, Fu J, Tandon N, Nadeau K, Urakami T, Barrett T, et al. ISPAD clinical practice consensus guidelines 2014. Type 2 diabetes in the child and adolescent. Pediatr Diabetes [Internet]. 2014 Sep [cited 2017 Apr 29];15(Suppl 20):26-46. Available from: https://www.ncbi.nlm.nih.gov/ pubmed/25182306

20. Ministério da Saúde (BR). Secretaria de Atenção à Saúde. Departamento de Atenção Especializada e Temática. Manual de terapia nutricional na atenção especializada hospitalar no âmbito do Sistema Único de Saúde - SUS [Internet]. 2016. [cited 2017 Apr 24]. Available from: http:// bvsms.saude.gov.br/bvs/publicacoes/manual_terapia_nutricional_atencao_especializada.pdf

21. Conselho Federal de Enfermagem (BR). Guia de recomendações para registro de Enfermagem no prontuário do paciente e outros documentos de Enfermagem [Internet]. 2015 [cited 2017 Apr 29]. Available from: http://www.cofen.gov.br/wp-content/uploads/2016/08/ Guia-de-Recomendações-CTLN-Versão-Web.pdf

22. Nascimento DM, Nóbrega MML, Carvalho MWA, Norat EM. Diagnósticos, resultados e intervenções de enfermagem para clientes hospitalizados submetidos à prostatectomia. Rev Eletronica Enferm [Internet]. 2011 [cited 2017 Nov 21];13(2):165-73. Available from: http:// dx.doi.org/10.5216/ree.v13i2.11117

23. Berzuino MB, Fernandes RCS, Lima MA, Matias ACG, Pereira IRO. Alergia alimentar e o cenário regulatório no Brasil. Rev Eletronica Farm [Internet]. 2017 [cited 2019 Feb 10];14(2):23-36. Available from: https://doi.org/10.5216/ref.v14i2.43433

24. Sicherer SH, Sampson HA. Food allergy: a review and update on epidemiology, pathogenesis, diagnosis, prevention, and management. J Allergy Clin Immunol [Internet]. 2018 [cited 2019 Feb 10];141:41-58. Available from: https://www.ncbi.nlm.nih.gov/pubmed/29157945

25. Castro MCF, Fuly PSC, Garcia TR, Santos MLSC. ICNP® terminological subgroup for palliative care patients with malignant tumor wounds. Acta Paul Enferm [Internet]. 2016 [cited 2018 Jan 22];29(3):340-6. Available from: http://dx.doi.org/10.1590/1982-0194201600047

26. Reis CEG, Vasconcelos IAL, Barros JFN. Políticas públicas de nutrição para o controle da obesidade infantil. Rev Paul Pediatr [Internet]. 2011 [cited 2018 Jan 22];29(4):625-33. Available from: http://dx.doi.org/10.1590/S0103-05822011000400024

27. Ministério da Saúde (BR). Saúde e estado nutricional de crianças menores de cinco anos [Internet]. 2008. [cited 2018 Jan 20]. Available from: http://bvsms.saude.gov.br/bvs/pnds/saude_nutricional.php

28. Coutinho JG, Gentil PC, Toral N. A desnutrição e obesidade no Brasil: o enfrentamento com base na agenda única da nutrição. Cad Saúde Pública [Internet]. 2008 [cited 2018 May 09];24(Suppl 2):332-340. Available from: http://dx.doi.org/10.1590/S0102-311X2008001400018

29. Verde SMML. Childhood Obesity: public health problem in the 21 century. Sao Paulo Med J [Internet]. 2011 [cited 2018 Jan 20];129(5):283284. Available from: http://www.scielo.br/pdf/spmj/v129n5/v129n5a01.pdf

30. Pedraza DF, Silva FA, Melo NLS, Araujo EMN, Sousa CPC. Estado nutricional e hábitos alimentares de escolares de Campina Grande, Paraíba, Brasil. Ciênc Saúde Coletiva [Internet]. 2017[cited 2018 Jun 12];22(2):469-477. Available from: http://dx.doi.org/10.1590/1413-81232017222.26252015 